\title{
Analisis Ruang Percepatan: Dinamika Pendidikan Di Era Pandemi Covid 19
}

\author{
Hanafi Saputra ${ }^{1}$ dan Yeni Marcelawati \\ Universitas Gadjah Mada
}

\begin{abstract}
This article aims to elaborate on the dynamics of the implementation of Indonesian education using the perspective of Paul Virilio's space for acceleration as a form of the phase of acceleration space during the Covid-19 crisis. Starting from the fact that education as the standard determining the country's progress has experienced segregation during the Covid-19 pandemic. Activities related to the transfer of knowledge, which can usually be carried out in a physical space with clear boundaries of space and distance, such as in educational institutions, suddenly shift to a space that is no longer limited by space and distance. These conditions then produce various dynamics that have an impact on the implementation of education. Because the use of space for acceleration in the world of education will have a significant impact on science. This is increasingly interesting, especially in connection with the condition of Indonesia, which still has various unresolved homework in the world of education. The data in this article were obtained from books, news, research reports, journals, and internet sources. By using a qualitative exploratory method through a literature approach to answering the question of how the dynamics of the implementation of Indonesian education in the midst of the Covid-19 pandemic in Paul Virilio's space for acceleration, it is known that online learning is a place to capitalize on the commodification of education through media platforms as an arena for implementing education. Besides, inequality in the distribution of capital such as facilities and access to learning creates increasingly visible gaps in society. Then the use of space for acceleration leads to a crisis of intelligence and a crisis of civilization in a country due to the inadequate implementation of education during the Covid 19 period.
\end{abstract}

Keywords: Speed Space, Education, Covid 19

\begin{abstract}
Abstrak
Artikel ini bertujuan untuk mengelaborasi dinamika implementasi pendidikan Indonesia dengan menggunakan perspektif ruang percepatan Paul Virilio sebagai bentuk fase ruang percepatan di masa krisis Covid-19. Berangkat dari kenyataan dimana pendidikan sebagai standar penentu kemajuan negara telah mengalami segregasi selama pandemi Covid-19. Aktivitas terkait transfer ilmu pengetahuan yang biasanya dapat dilakukan dalam ruang fisik dengan batas ruang dan jarak yang jelas seperti di institusi pendidikan, seketika beralih pada space yang tidak lagi dibatasi ruang dan jarak. Kondisi tersebut kemudian menghasilkan berbagai dinamika yang berdampak pada pengimplemantasian pendidikan. Sebab pemanfaatan ruang percepatan dalam dunia pendidikan akan memberikan dampak yang signifikan terhadap ilmu pengetahuan. Hal itu semakin menarik terlebih dikaitkan dengan kondisi Indonesia yang masih memiliki berbagai pekerjaan rumah dalam dunia pendidikan yang belum teratasi. Data dalam artikel ini diperoleh dari buku, berita, laporan hasil penelitian, jurnal dan sumber internet. Dengan menggunakan metode kualitatif eksploratif melalui pendekatan kepustakaan untuk menjawab pertanyaan bagaimana
\end{abstract}

\footnotetext{
${ }^{1}$ saputra.hanafi25@gmail.com
} 
dinamika implementasi pendidikan Indonesia di tengah pandemi Covid-19 pada ruang percepatan Paul Virilio, maka diketahui pembelajaran daring menjadi ajang kapitalisasi atas komodifikasi pendidikan melalui media platform sebagai arena implementasi pendidikan. Selain itu, ketimpangan akan distribusi capital seperti fasilitas dan akses pembelajaran melahirkan kesenjangan yang semakin tampak di tengah masyarakat. Kemudian pemanfaatan ruang percepatan berujung pada krisis kecerdasan dan krisis peradaban suatu negara akibat ketidakmaksimalan implementasi pendidikan dimasa covid 19.

Kata Kunci: Ruang Percepatan, Pendidikan, Covid 19

\section{Pendahuluan}

Pendidikan mengalami segregasi akibat keberadaan pandemi Covid-19. Pergeseran aktivitas pendidikan dari penggunaan ruang fisik nyata menuju ke ranah penggunaan ruang percepatan melalui perkembangan teknologi membawa dinamika pendidikan Indonesia menuju laju percepatan yang belum dimbangi dengan ketersediaan akses untuk memperoleh pendidikan itu sendiri. Sebuah kompleksitas permasalahan yang telah ada dan saat ini semakin terpuruk perihal kemampuan dalam berdinamika di dunia pendidikan. Dengan kompleksitas permasalahan akses yang ada di tengah pandemi Covid 19, batas ruang dan jarak yang jelas pada ruang fisik seperti institusi pendidikan seketika beralih pada space yang tidak lagi mengenal batas ruang dan jarak bahkan waktu (fleksibel). Fleksibilitas dan efisiensi dalam pendidikan tidak serta merta dapat tercapai dengan hadirnya terobosan teknologi.

Pencapaian atas terealisasi atau tidaknya dari pengimplentasian pendidikan menjadi tantangan atas kehadiran kapitalisme global yang menyusup di tengah dinamika pendidikan era pandemi covid 19. Disadari atau tidak atmosfir pendidikan saat ini nampak berhasil membawa kapitalisme dengan tameng alternatif teknologi menjadi jaring-jaring perangkap sebagai bentuk ekspansi kekuasaan kapitalis. Dampaknya kemudian menghasilkan berbagai dinamika pada pengimplemantasian pendidikan. Pemanfaatan ruang percepatan dalam dunia pendidikan akan memberikan konsekuensi yang signifikan terhadap ilmu pengetahuan.

Salah satu dinamika pendidikan dalam aspek mental health disebutkan dalam salah satu penelitian yang membahas mengenai dampak Covid-19 pada siswa dan staf perguruan tinggi. Kenyataan yang harus dihadapi perguruan tinggi untuk 
menghambat penyebaran virus berujung pada penerapan pembelajaran daring di tingkat universitas. Sehingga pengimplentasian pendidikan semacam ini ditunjang dengan menyediakan layanan konseling untuk mendukung kesehatan mental dan kepedulian pelajar. Serta menggunakan teknologi dan perhatian penuh untuk meningkatkan dan mengefektifkan pembelajaran. (Sahu, 2020)

Dinamika pendidikan pada aspek mental health lainya juga termuat dalam penelitian yang menerapkan Universal Design for Learning (UDL) sebagai alternatif pendidikan selama penerapan pembatasan sosial, isolasi, dan karantina di masa pandemi Covid-19. (Dickinson \& Gronseth, 2020) Studi naratif dampak covid-19 selama enam minggu pertama ini mengungkap penerapan lockdown telah mengakibatkan peningkatan stres pada guru di United Kingdom. Kondisi itu disebabkan oleh pengalaman atas ketidakmampuan berdamai dengan pekerjaan yang berujung sebagai sumber kestresan. (Kim \& Asbury, 2020)

Kenyataan terkait transformasi dan dinamika pendidikan saat ini menjadi menarik terlebih jika dikaitkan dengan kondisi Indonesia yang masih memiliki berbagai pekerjaan rumah dalam dunia pendidikan yang belum teratasi. Dewasa ini dilema penggunaan platform untuk menunjang pendidikan era pandemi turut menyumbang terjadinya dinamika implementasi pendidikan. Pertama, Hasil riset yang dikemukakan oleh Jacob, Abigel \& Lydia (2020) melihat dampak covid terhadap perkembangan perguruan tinggi di Nigeria. Siswa menggunakan varian platform dalam belajar, diantaranya Zoom app, Team link, YouTube live, Skype, Google meets/hangout, Google classroom, WhatsApp. Penggunaan platform lebih pada berbagi materi pembelajaran daripada kehadiran online akibat keterbatasan koneksi internet. (Jacob, Abigel, \& Lydia, 2020). Penggunaan platform juga digunakan dalam tahap evaluasi pembelajaran yang lebih cepat dengan menggunakan WhatsApp group. Hasil presentasinya sebesar $40.5 \%$ dari 232 responden, Google classroom dengan presentasi 24.9\% dari 232 responden, Google form, dan Microsoft Kaizala. (Kapasia, et al., 2020).

Kajian kedua mengenai dampak Covid-19 terhadap pendidikan dokter gigi di Amerika, menyimpulkan bahwa pendidikan dokter gigi di Amerika lebih pada mengevaluasi ulang bentuk pembelajaran jarak jauh yang dilakukan, dan lebih 
fokus pada memprioritaskan kebijakan dan protokol penanganan kasus masa depan pandemi. (Iyer BDS DDS, Aziz, \& Ojcius, 2020). Covid-19 memberikan dampak terhadap pembelajaran kedokteran gigi dimana penggunaan platform untuk pembelajaran teori selama era covid-19, baik pra-praktek dan praktek melalui elearning berdampak pada Kesehatan mental anggota, professor, teknikal, dan juga pelajar. Penelitian ini lebih pada pemaparan secara deskriptif dampak covid-19 terhadap dunia pendidikan. (Machado, Bonan, Pezer, \& Júnior, 2020).

Perkembangan narasi mengenai kemajuan teknologi tidak terlepas dari kenyataan bahwasanya pada pengimplementasian pendidikan tidak sekedar berdinamika ke arah positif namun dilema yang hadir membawa bayangan distorsi terhadap proses pembelajaran. Salah satunya praktek pada mahasiswa postgraduate di Orthopaedic New Delhi India. Studi riset oleh Upadhayaya,dkk ini memaparkan bahwasanya pemerintah dan organisasi pembelajaran di New Delhi diharapkan mampu menangani kondisi secara serius, dan menghasilkan sebuah mekanisme penyelesaian masalah dengan solusi yang masuk akal. (Upadhayaya, Jain, Iyengar, Patralekh, \& Vaish, 2020).

Selanjutnya studi mengenai alternatif pengimplementasian pendidikan juga memberikan penawaran bentuk alternatif metode pembelajaran jarak jauh bagi siswa. Penggunaan teknologi yang menarik affordable dan bisa diimplementasikan dengan cepat dalam program pendidikan cytology. (Chiou, 2020). Upaya atas permasalahan dan dinamika pengimplementasian pendidikan selama pandemi covid 19 yang telah diuraikan terbatas pada fokus kesehatan, alternatif pembelajaran dan dampak pada institusi pendidikan. Namun kajian mengenai perspektif speed space dalam dinamika pendidikan Indonesia belum didalami pada studi-studi terdahulu.

Oleh sebab itu, fokus dalam paper ini akan mengkaji studi mengenai analisis ruang. Menyoal bagaimana dinamika implementasi pendidikan Indonesia yang berujung kapitalisasi pendidikan di tengah pandemi Covid-19 pada ruang percepatan Paul Virilio. Kontestasi dunia pendidikan dalam bingkai ruang percepatan yang beriringan dengan teknologi akankah menjadi alternatif ataukah justru bagian dari kapitalisasi pembelajaran daring melalui media platform. 


\section{Metode Penelitian}

Metode penelitian yang digunakan dalam artikel ini yaitu bersifat kualitatif dengan analisis eksploratif berdasarkan data sekunder. Dengan pendekatan kepustakaan atau literature review disertai pemaparan data yang relevan terkait dinamika pendidikan era pandemi covid 19. Dalam hal ini fokus kajian pada dinamika pendidikan era pandemi covid 19 yang terjadi di Indonesia menggunakan teknik analisis data yaitu dengan menelaah dan mengkaji sumber data relevan dengan dinamika pendidikan. Data tersebut kemudian dianalisis dan dikaitkan dengan preposisi berdasarkan teori Speed space oleh Paul Virilio. Sumber data dalam artikel ini diperoleh dari laporan hasil penelitian, artikel berita, buku, jurnal dan sumber internet yang dianggap relevan terkait dinamika pendidikan era pandemi covid 19.

\section{Hasil dan Pembahasan}

Mengelaborasi dinamika implementasi pendidikan Indonesia dengan menggunakan perspektif ruang percepatan Paul Virilio sebagai bentuk fase ruang percepatan di masa krisis Covid-19 dipaparkan dalam beberapa sub bahasan. Pertama, pembahasan terkait dinamika pendidikan dalam perspektif Speed Space Paul Virilio. Kedua, Krisis kecerdasan dan krisis peradaban suatu negara akibat ketidakmaksimalan implementasi pendidikan dimasa covid 19. Ketiga, ketimpangan dan komodifikasi platform pembelajaran digital. Berikut uraian dan telaah dinamika pendidikan di era pandemi covid 19.

\section{Dinamika pendidikan dalam perspektif Speed Space Paul Virilio}

Keberadaan virus Covid-19 telah memberikan dampak ke berbagai ranah, terutama ranah pendidikan. Sejak pengumuman resmi yang disampaikan oleh Presiden Joko Widodo pada tanggal 2 Maret 2020 terkait penemuan kasus pertama Covid-19 di Indonesia (Nasir et al., 2020). Pandemi telah mengakibatkan krisis yang berujung pada lahirnya berbagai segregasi dalam bidang pendidikan. Hal itu tidak terlepas dari penyebaran virusnya yang semakin hari semakin tidak dapat terelakan (Telaumbanua, 2020). 
Mengingat kondisi yang semakin hari semakin memburuk, pemerintah kemudian menerapkan Pembatasan Sosial Berskala Besar atau yang disingkat PSBB sesuai Peraturan Pemerintah Nomor 21 tahun 2020, aktivitas dan interaksi masyarakat kemudian dibatasi (Syafrida, 2020). Semua aktivitas yang biasanya dapat dilakukan di luar rumah atau di ruang publik, seketika beralih pada ruang privat. Kenyataan tersebut turut dialami dalam proses implementasi pendidikan.

Aktivitas pendidikan yang biasanya dilakukan pada ruang fisik nyata seperti pada institusi pendidikan (sekolah), seketika beralih pada ruang privat yang hanya dapat diakses secara terbatas (rumah). Kondisi tersebut menuntut adanya proses adaptasi dalam implementasi pendidikan terhadap kondisi baru yang dialami. Menghadapi hal itu, maka lahirlah bentuk alternatif baru dalam proses implementasi pendidikan. Aktivitas yang biasanya dilakukan dalam batas ruang dan waktu yang jelas di sekolah, seketika beralih pada penggunaan platform atau aplikasi yang dapat mendukung terlaksananya aktivitas pembelajaran. Aplikasi tersebut seperti penggunaan Zoom, Google Meet, Webex, dan WhatsApp Group, hingga berbagai aplikasi lainnya. (Erni et al., 2020)

Faktanya, tingkat penggunaan aplikasi semacam itu menunjukan tren peningkatan selama pandemi Covid-19. Hal itu, seperti yang ditunjukan pada tabel berikut:

Tabel.1

Perkembangan Penggunaan Platform Digital

\begin{tabular}{|l|l|l|l|l|}
\hline & 28 Feb - 5 Maret & 6-12 Maret & 13-19 Maret & 20-26 Maret \\
\hline Zoom & 8.714 & 8.985 & 91.030 & 257.853 \\
\hline Hangouts Meet & 1.448 & 1.554 & 7.917 & 10.454 \\
\hline Cisco Web Meeting & 3.983 & 4.123 & 8.257 & 8.748 \\
\hline Go to Meeting & 479 & 505 & 696 & 977 \\
\hline
\end{tabular}

sumber: Statco Analytics, 2020

Dari tabel di atas terlihat bahwa adanya peningkatan pengguna pada aplikasi Zoom, dimana tertanggal 28 Februari hingga 5 Maret 2020 penggunaan aplikasi Zoom mengalami peningkatan sebanyak 271 pengguna. Jumlah penggunanya kemudian mengalami lonjakan yang signifikan pada periode 13-19 Maret, dimana naik sebanyak 82.045. Bahkan peningkatan yang makin luar biasa 
terjadi pada periode 20-26 maret dengan penambahan 166.823 pengguna. Kondisi yang sama juga dialami aplikasi Hangout Meet dimana penggunaannya mengalami peningkatan sebanyak 106 dari periode sebelum 6-12 Maret. Kemudian turut melonjak sebanyak 6.363 pada periode 13-19 Maret, dan juga mengalami peningkatan sebanyak 2.537 pada periode 20-26 Maret. Tren peningkatan penggunaan aplikasi ini juga turut terjadi pada aplikasi Cisco Web Meeting dan Gotomeeting.

Berangkat dari kenyataan atas adanya peningkatan penggunaan aplikasi atau platform dalam implementasi pendidikan, maka hal itu menegaskan bahwa penggunaan ruang percepatan sebagaimana yang disampaikan oleh Paul Virilio telah terjadi di tengah-tengah masyarakat. Hal ini senada dengan apa yang Virilio katakan dengan ruang percepatan, yaitu kondisi dimana kaburnya bahkan hilangnya batas ruang dan jarak serta waktu di tengah-tengah masyarakat, akibat adanya perkembangan teknologi (Virilio,1986). Hal itu terlihat dari penggunaan aplikasi dalam pendidikan telah berujung pada pengaburan bahkan penghilangan batas ruang dan jarak. Pembelajaran yang pra-pandemi dilakukan di ruang fisik atau ruang real seperti sekolah dengan batas ruang, jarak, dan waktu jelas menuju ruang percepatan yang tidak lagi dibatasi batas, waktu, dan jarak. Pelaksanaan pendidikan telah dilakukan melalui daring dimana keberadaan pendidik dan peserta didik tidak lagi berada pada ruang fisik yang sama. Mereka berada di ruangan atau lokasi yang berbeda, dan juga dalam jarak yang berbeda, namun dipersatukan dalam satu ruang percepatan melalui aplikasi yang bersifat virtual.

Penguatan penggunaan platform digital dalam dunia pendidikan, mengisyaratkan semakin trennya pemanfaatan ruang percepatan melalui keberadaan teknologi. Kenyataan itu turut didukung seiring dengan keluarnya surat edaran Menteri Pendidikan dan Kebudayaan Republik Indonesia nomor 4 tahun 2020 pada tanggal 24 Maret 2020 tentang pelaksanaan kebijakan pendidikan dalam masa darurat penyebaran Covid-19. Surat edaran itu menegaskan bahwa proses pembelajaran (belajar dan mengajar) dilaksanakan di rumah melalui pembelajaran daring atau jarak jauh untuk memberikan pengalaman bermakna bagi siswa. (Dewi, 2020) 
Lebih lanjut, penggunaan ruang percepatan ini juga di didukung oleh pemerintah dengan merilis aplikasi yang bernama Aplikasi Ruang Belajar (ARB). Guru dan siswa dapat mengakses aplikasi itu melalui laman situs https://belajar.kemdikbud.go.id/. Tujuannya untuk memberikan kemudahan bagi guru dan siswa dalam memperoleh materi pembelajaran dan melakukan simulasi interaktif, termasuk interaksi antar pendidik. (Erni et al., 2020) Kenyataan demikian jelas kemudian mempertegas bahwa penggunaan ruang percepatan telah menjadi tren dalam dunia pendidikan.

Krisis Kecerdasan dan Krisis Peradaban Suatu Negara Akibat

\section{Ketidakmaksimalan Implementasi Pendidikan Dimasa Covid 19}

Seiring semakin populernya penggunaan platform aplikasi dalam proses pembelajaran di masa pandemi Covid-19 di Indonesia, berbagai kelemahan turut terjadi. Jika mengacu pada hakikat pembelajaran, Sudirman (2004), pembelajaran merupakan suatu proses perubahan yang mengacu pada aspek perubahan tingkah laku (Mansyur, 2020). Pendidikan yang sejatinya berkaitan dengan adanya interaksi pendidik dan peserta didik dan adanya proses transfer of knowledge and transfer of morality, mengalami keterbatasan atau bahkan mengalami kekurangan hakikatnya dari pendidikan saat pembelajaran dilakukan melalui daring atau online. Kenyataan itu tampak dari kenyataan dimana pembelajaran online berakibat pada hilangnya fungsi pendidikan terkait transfer of morality.

Bergesernya atau bahkan hilangnya proses interaksi yang bersifat langsung antara pendidikan dengan peserta didik menjadi salah satu penyebab utamanya. Pendidik cenderung fokus pada pelajaran yang hanya lebih pada pemberian materi pembelajaran, namun pendidik tidak dapat melakukan kontrol langsung pada peserta didik terkait penerapan nilai norma yang sejatinya turut menjadi tujuan pendidikan itu. Seperti yang Virilio paparkan bahwasanya masyarakat tidak perlu lagi melakukan interaksi secara langsung dalam ruang dan waktu yang sama (Virilio,1986). Jika dikaitkan dalam dunia implementasi pembelajaran daring, maka hal itu menegaskan terjadinya kekosongan peran dan fungsi pendidik dalam proses pembelajaran. 
Penerapan pembelajaran jarak jauh atau daring menggunakan fasilitas yang diberikan dari adanya perkembangan teknologi turut berdampak pada ketidak maksimalan proses transfer of knowledge. Buktinya, penerapan pendidikan daring selama pandemi telah berakibat pada tidak maksimalnya pengimplementasian pendidikan. Sistem penilaian pun mengalami penyederhanaan akibat keterbatasan yang terjadi selama pendidikan daring diterapkan. Akibatnya, berujung pada sistem evaluasi dan penilaian yang tidak lagi sesuai dengan seharusnya. Maka tidak mengherankan kemudian berdampak pada ketidak transparanan hasil penilaian pembelajaran peserta didik. (Mansyur, 2020)

Mengacu pada beberapa hasil penelitian terkait penerapan pendidikan daring di Indonesia, ternyata jika dilihat pada perspektif ruang percepatan Paul Virilio, terdapat menunjukan terjadi beberapa kendala dalam proses pengimplementasianya di Indonesia. Hal itu dinilai sebagai bentuk dampak dari penerapan ruang percepatan di Indonesia dalam aplikasi pendidikan during selama covid-19. Adapun kendala dalam penerapan sistem pembelajaran daring di Indonesia tersebut dapat dikelompokan dalam beberapa point.

Pertama, kondisi dimana masih banyak pendidik yang memiliki keterbatasan akses dan pemanfaatan teknologi yang dimiliki. Pendidik di Indonesia belum memiliki kemampuan yang sama untuk mengoperasikan dan memanfaatkan kecanggihan teknologi. Bagi kelompok pendidik yang melek teknologi, tentu hal ini tidak menjadi masalah. Sebaliknya, bagi kelompok pendidik yang masih gagap teknologi, pembelajaran daring jarak jauh akan menjadi kendala. Padahal, pembelajaran daring menjadikan kreativitas sebagai kunci dalam proses pembelajarannya. Kreativitas ini berkaitan dengan pembuatan materi yang menarik serta memanfaatkan kelebihan media daring yang digunakan. Artinya, pendidik harus pintar mengkreasi materi pelajaran agar mudah dipahami oleh peserta didik dengan memanfaatkan media daring yang ada. Namun kenyataan yang ada, kapasitas pendidik dalam menghadapi daring masih bersifat prematur, sebab mereka mengalami cultural shock dalam menjalankan pembelajaran daring. 
Kedua, kemandirian belajar peserta didik di rumah tidak dapat sepenuhnya terlaksana dengan baik. Kemandirian belajar menjadi tuntutan yang harus dipenuhi dalam pembelajaran daring. Keterbatasan untuk bertatap muka langsung dengan pendidik, membuat peserta didik harus mandiri dalam memahami materi dan mengerjakan tugas yang ada. Mereka harus mampu memahami dengan baik materi yang diberikan. Ketidak pahaman atau miskonsepsi suatu materi mungkin saja terjadi. Apalagi jika materi yang diberikan, butuh penjelasan yang lebih detail dan mendalam. Sebab, ketidak pahaman materi yang disajikan, harus segera memperoleh penjelasan lebih lanjut. Kondisi tersebut merupakan salah satu dampak penggunaan ruang percepatan dalam pembelajaran daring. Ketiga, tugas dan pekerjaan rumah yang diberikan kepada peserta didik ternyata membebani. Pembelajaran daring seyogyanya tidak membeban, dan memberikan ruang kebebasan dalam aktivitas belajarnya.

Keempat, tidak semua siswa mempunyai gawai (handphone). Gawai merupakan alat utama yang digunakan untuk pembelajaran daring. Tetapi, tidak semua siswa mempunyai alat komunikasi ini. Mungkin, bisa saja gawai menjadi barang mewah bagi siswa dari kalangan ekonomi tidak mampu. Akibatnya, siswa tidak punya fasilitas pembelajaran daring.

Kelima, pembelajaran daring terkendala dengan sinyal internet yang tidak stabil dan pulsa (kuota data) yang mahal. Kita tahu, bahwa Indonesia mempunyai kondisi geografis yang beragam. Keragaman kondisi letak geografis rumah siswa yang beragam menjadi masalah terutama terkait kestabilan sinyal internet. Rumah siswa ada yang di dataran rendah, seperti dataran biasa dan tepi laut. Ada juga siswa yang tinggal di dataran tinggi, seperti di pegunungan atau lereng gunung. Ada yang tinggal di kota, dan ada pula siswa yang tinggal di desa. Kestabilan sinyal internet diperlukan agar dalam proses pembelajaran tidak terganggu sehingga siswa dapat mengikuti pembelajaran dengan baik. Akan tetapi tidak hanya sinyal, pulsa (kuota data) internet juga harus cukup tersedia. Padahal pembelian pulsa (kuota) data memerlukan biaya yang tidak murah. 


\section{Ketimpangan dan Komodifikasi Platform Pembelajaran Digital}

Kondisi ketimpangan pendidikan di Indonesia pada masa pra pandemi covid 19 menunjukan heterogenitas permasalahan yang kompleks. Salah satunya studi oleh Suratman et al., (2014) mengungkap perihal gender gap dalam dunia pendidikan. Kesetaraan dan keadilan dalam memperoleh akses pendidikan atas diskriminasi gender menjadi penyumbang ketimpangan pendidikan. Lebih jauh permasalahan tentang kualitas/mutu pendidikan, pemerataan, efisiensi dan efektifitas serta relevan atau tidak nya sistem pendidikan dan pengimplementasian sistem yang ada menjadi tantangan yang belum terselesaikan. Ironisnya ketimpangan masih langgeng dan menjadi kesenjangan pendidikan di era pandemi covid 19.

Pembelajaran digital laksana yang disampaikan Paul Virilio tentang ruang percepatan di Indonesia dengan dalih mempermudah transfer ilmu telah menggilas jarak, ruang dan waktu. Dampaknya, komodifikasi turut menyasar kebijakan pemerintah yang terlihat dari munculnya anjuran Mendikbud RI dalam penggunaan google classmeet, zoom meeting, dan aplikasi lainnya untuk implementasi pendidikan. Padahal aplikasi ARB dari Kemendikbud merupakan platform yang sebenarnya lahir untuk menunjang pembelajaran daring. (Erni et al., 2020) Realitasnya, ketimpangan pendidikan di masa covid 19 di Indonesia dikokohkan atas dukungan kapitalisasi media platform dan komodifikasi pembelajaran daring.

Komodifikasi melalui media platform yang merujuk pada kebijakan bantuan pulsa dengan alokasi data untuk siswa sebanyak $35 \mathrm{~GB} / \mathrm{bulan}$, guru sebanyak 42 GB/bulan, mahasiswa dan dosen sebanyak 50 GB/bulan. (Tirto.id, 2020). Namun dalam implementasinya, fasilitas dari rincian kuota yang disediakan terbatas pada media platform tertentu. Sorotan komodifikasi pada relasi antar aktor kebijakan pemerintah dan korporasi yang menaungi platform menonjolkan dominasi aplikasi tertentu untuk bantuan kuota belajar. Sedangkan pada prakteknya peserta didik tidak hanya terpaku pada platform yang bekerjasama dengan fasilitas bantuan yang disediakan pemerintah. Pembelajaran digital menjadi ajang kapitalisasi dan mendominasi pengguna platform tanpa pandang status baik guru, dosen, mahasiswa, pelajar bahkan di seluruh institusi sosial. Mengingat 
ketidakberdayaan institusi pendidikan yang memanfaatkan media platform untuk pembelajaran atas kuasa dominasi korporasi dari ekspansi kapitalis yang meraup keuntungan di tengah pembelajaran digital pandemi covid 19.

Implementasi pendidikan dan pembelajaran di era digital tidak luput dari serbuan komodifikasi platform. Kapitalisme menyulut hadirnya ketimpangan dan ketidakmerataan atas akses maupun fasilitas untuk menggunakan platform pembelajaran. Akses yang tidak merata menimbulkan dampak distribusi kapital yang hanya dapat dicapai oleh kelas sosial tertentu. Menyoal distribusi kapital, permasalahan penggunaan platform tertentu akan berelasi dengan perekonomian atau penghasilan keluarga peserta didik. Kepemilikan smartphone maupun alat komunikasi sejenis merupakan fasilitas dasar yang kini menjerat keluarga peserta didik dengan kelas sosial bawah dan memaksa pemenuhan kebutuhan tersebut.

Implikasi mengenai akses platform lainnya terhubung pada kualitas atau mutu pembelajaran. Kondisi geografis Indonesia yang beragam menjadikan peserta didik yang berada di daerah pelosok/terpencil terkendala dalam sinyal. Ketimpangan juga terjadi pada aspek kepemilikan sumber kapital yang berkaitan dengan meminimalisir kendala efektifitas dan efisiensi pembelajaran digital. Jika pada keluarga yang mampu dimungkinkan orang tua akan menyiasati dengan menyewa tentor atau guru privat untuk pendampingan selama pembelajaran digital sehingga resiko akan kualitas dan mutu pembelajaran dapat diminimalisir. Namun hal ini bertolak belakang dan tidak dapat dilakukan oleh peserta didik yang memiliki latar belakang ekonomi kurang mampu. Anggota keluarga lebih berfokus untuk memenuhi kebutuhan primer dan tidak ada sumber alokasi dana tambahan untuk pendamping atau tentor dalam belajar online. Hal demikian yang menjadi pemicu distribusi kapital yang tidak merata dan resiko yang menghantam kelas menengah bawah bahkan pada masa pandemi covid 19. Kenyataan itu menjadi penegas dampak dari penerapan ruang percepatan Paul Virilio dalam dunia pendidikan Indonesia di tengah pandemi Covid-19.

Berbeda dengan peserta didik dengan latar belakang ekonomi kurang yang berada di daerah perkotaan. Kelumpuhan karena perangkap teknologi yang mungkin menjebak dan menimbulkan permasalahan akses media platform tidak 
melenyapkan aspek solidaritas antara peserta didik. Padahal dalam perspektif Virilio, penggunaan teknologi dan akses akan teknologi tersebut merupakan kunci dalam ruang percepatan, termasuk implementasi pendidikan. Dilansir dari media online Kompas TV (2020) menyebutkan adanya sejumlah siswa yang setiap hari dapat mengakses pembelajaran digital melalui tetangga dan bale-bale dikarenakan tidak memiliki akses wifi dan perangkat smartphone untuk belajar. Aspek solidaritas yang tercermin dari antusiasme masyarakat dan tetangga sekeliling rumah menjadi alternatif informal yang hadir sebagai respon permasalahan pembelajaran digital di lingkup tetangga.

Bertolak dengan fenomena peserta didik dengan latar belakang ekonomi mampu atau kelas menengah atas yang tinggal di area pemukiman elite. Tanpa harus bersikeras untuk mencari sumber daya pendukung, akses pembelajaran digital dapat diperoleh dengan mudah karena kepemilikan wifi maupun smartphone telah terpenuhi. Namun dibalik ketersediaan akses, aspek individualistik dan eksklusifitas justru terinternalisasi dalam masa pembelajaran. Tidak adanya kekhawatiran atau aspek sosial antar peserta didik di lingkungan kelas atas yang setara untuk mengkhawatirkan satu dengan yang lainya.

\section{Kesimpulan}

Dinamika dalam pembelajaran digital era pandemic Covid 19 menemui tantangan dan kendala yang memerlukan perhatian pada aspek yang langgeng baik sebelum dan ketika pandemic Covid 19 berlangsung. Implementasi ruang percepatan Paul Virilio ternyata berujung pada kegamangan dalam aplikasi pendidikan di Indonesia di masa pandemi Covid-19, khususnya pada aspek ketimpangan, pemerataan, mutu/kualitas, kebijakan pembelajaran daring dan akses/keterjangkauan pendidikan. Target utamanya penerapan ruang percepatan ini tidak lain untuk memudahkan dalam mencapai pembelajaran digital yang maksimal. Institusi pendidikan hendaknya bertransformasi dengan mempersiapkan inovasi sesuai kebutuhan dan pada tingkatan setiap jenjang pendidikan. Perlunya kontrol atas implementasi pendidikan jangka pendek untuk mewujudkan pendidikan yang inklusif. Selain itu perlunya penekanan akan penyediaan fasilitas penunjang dan 
kemampuan adaptasi tenaga pendidik pada speed space yang telah meruntuhkan ruang dalam jarak dan waktu. Pengembangan kebijakan informal tentang transformasi pendidikan hendaknya dapat diimplementasikan oleh masyarakat dan didukung stakeholder terkait sebagai alternatif pembelajaran yang adaptif. Sehingga, dengan kolaborasi bersama dan pertimbangan serta perhatian bersama, target positif pemanfaatan ruang percepatan dapat diperoleh dengan maksimal. Ketimpangan pendidikan yang lahir di tengah masyarakat akibat implementasi ruang percepatan Paul Virilio tersebut dapat teratasi.

\section{Daftar Pustaka}

Alqudah, N., Jammal, H., Saleh, O., Khader, Y., Obeidat, N., \& Alqudah, J. (2020). Perception and Experience of Academic Jordanian Ophtalmologists with ELearning for Undergraduate Course During the Covid-19 Pandemic. Annals of Medicine and Surgery, 44-47.

Chiou, P. (2020). Learning Cytology in Times of Pandemic: An Educational Institutional Experience with Remote Teaching. ScienceDirect, 579-585.

Dewi, W. A. F. (2020). Dampak COVID-19 terhadap Implementasi Pembelajaran Daring di Sekolah Dasar. Edukatif: Jurnal Ilmu Pendidikan, 2(1), 55-61. https://doi.org/10.31004/edukatif.v2i1.89

Dickinson, K., \& Gronseth, S. (2020). Application of Universal Design for Learning (UDL) Principles to Surgical Education During the Covid-19 Pandemic. Perspectives: Journal of Surgical Education, 1008-1012.

Erni, S., Vebrianto, R., Miski, C. R., MZ, Z. A., Martius, \& Thahir, M. (2020). Refleksi Proses Pembelajaran Guru MTs dimasa Pendemi Covid 19 di Pekanbaru: Dampak dan Solusi. Journal of Education and Learning, 1(1), $1-10$.

Haris Prabowo. 2020. Bantuan Pulsa Guru, Siswa \& Dosen Rp9 T dari Nadiem, Ini Rinciannya. diakses dari https://tirto.id/bantuan-pulsa-guru-siswa-dosenrp9-t-dari-nadiem-ini-rinciannya-f1Ji (27 Agustus 2020)

Iyer BDS DDS, P., Aziz , K., \& Ojcius, D. (2020). Impect of Covid-19 on Dental Education in the United States. ADEA: The Voice of Dental Education Wiley, 1-5.

Jacob, O. N., Abigel, I., \& Lydia, A. (2020). Impact of Covid-19 on the Higher Institutions Development in Nigeria. Journal of Social Sciences and Humanities Vol 2 Issue II, 126-135.

Kapasia, N., Paul, P., Roy, A., Saha, J., Zaveri, A., Mallick, R., . . Chouhan, P. (2020). Impact of Lockdown on Learning Status of Undergraduate and Postgraduate Studients during Covid-19 Pandemic in West Bengal, India. Elsevier: Children and Youth Services Review, 1-5. 
Kim, L., \& Asbury, K. (2020). 'Like a Rug Had Been Pulled from Under You': The Impact of Covid-19 on Theacher in England during the First Six Weeks of the UK Lockdown. The British Psychological Society, 1062-1083.

Kompas TV Makasar. (2020) . Belajar Daring, Siswa Pinjam Ponsel Dan Numpang Wifi Tetangga diakses dari https://www.kompas.tv/article/115266/belajardaring-siswa-pinjam-ponsel-dan-numpang-wifi-tetangga ( 12 Oktober 2020)

Machado, R. A., Bonan, P. R., Pezer, D. E., \& Júnior, H. M. (2020). Covid-19 Pandemic and the Impect on Dental Education: Discussuing Current and Future Perspectives. Critical Riview Oral Pathology, 1-6.

Mansyur, A. R. (2020). Dampak COVID-19 Terhadap Dinamika Pembelajaran Di Indonesia. Education and Learning Journal, 1(2), 113. https://doi.org/10.33096/eljour.v1i2.55

Nasir, N. M., Baequni, B., \& Nurmansyah, M. I. (2020). Misinformation Related To Covid-19 in Indonesia. Jurnal Administrasi Kesehatan Indonesia, 8(2), 51. https://doi.org/10.20473/jaki.v8i2.2020.51-59

Ritzer, George, 2003, Teori Sosiologi Postmodern, Yogyakarta: Penerbit Kanisius

Sahu, P. (2020). Clousure of Universities Due to Coronavirus Disease and Mental Health of Students and Academic Staff. Cureus, 1-6.

Suratman, B., Soesatyo, Y., \& Soejoto, A. (2014). Analisis faktor yang mempengaruhi ketimpangan pendidikan. Jurnal Ilmu Pendidikan, 2(20), $176-182$.

Syafrida, S. (2020). Bersama Melawan Virus Covid 19 di Indonesia. SALAM: Jurnal Sosial Dan Budaya Syar-I, 7(6). https://doi.org/10.15408/sjsbs.v7i6.15325

Telaumbanua, D. (2020). Urgensi Pembentukan Aturan Terkait Pencegahan Covid19 di Indonesia. QALAMUNA: Jurnal Pendidikan, Sosial, Dan Agama, 12(01), 59-70. https://doi.org/10.37680/qalamuna.v12i01.290

Upadhayaya, G. K., Jain, V. K., Iyengar, K., Patralekh, M. K., \& Vaish, A. (2020). Impact of Covid-19 on Post-graduate Orthopaedic Training in Delhi-NCR. Journal of Clinical Orthopaedich and Traauma, S687-S695.

Virilio, P. (1986) Speed and Politics, trans. M. Polizzotti, New York: Semiotext(e). 